\title{
Stakeholders Analysis of Policy-Making Process: The Case of Timber Legality Policy on Private Forest
}

\author{
Mulyaningrum $^{1 *}$, Hariadi Kartodihardjo ${ }^{2}$, I Nengah Surati Jaya ${ }^{2}$, Bramasto Nugroho $^{2}$ \\ ${ }^{1}$ Graduate School of Bogor Agricultural University, Dramaga Main Road, Campus IPB Dramaga, Bogor 16680, Indonesia \\ ${ }^{2}$ Department of Forest Management, Faculty of Forestry, Bogor Agricultural University, Academic Ring Road, Campus IPB \\ Dramaga, PO Box 168, Bogor 16680, Indonesia
}

Received May 23, 2013/Accepted Ausgust 2, 2013

\begin{abstract}
The objective of the study is to identify and measure the relationships among stakeholders that influence the process of policy-making in defining legality of timber from private forests. The study focuses on the policy-making process of the Ministry of Forestry Regulation P.38/Menhut-II/2009 on Standard and Guidelines for Assessment of Sustainable Forest Management Performance and Timber Legality Verification of Concessionaire or of the Private Forest License Holder as the subject that has been implemented in several private forest management units as follow: Giri Mukti Wana Tirta in Lampung, Koperasi Serba Usaha APIK in Bali, Koperasi Hutan Jaya Lestari in South East Sulawesi, and Koperasi Wana Lestari Menoreh Kulonprogo in Yogyakarta. This research used a qualitative approach and the analysis method used in this research is a modified-stakeholder analysis that developed by ODA (1995), Reitbergen et al. (1998), and Mayer (2005). The stakeholder analysis shows that the interests and influences do not consider private forest farmers as primary stakeholder during the process of policy formulation. The strong national and international interests, supported by high authority could not be influnced by the role of the NGOs and academicians. The imbalance of responsibilities, rights, and revenues that was experienced by farmers as the manager of private forest when started implementing the policy was more as burdens, it means implementation of the policy was more as burdens. Strong relationships between the Ministry of Forestry with the state as a core could not empower the relationship with private forest farmers. As result, policy assumptions cannot be implemented properly.
\end{abstract}

Keywords: policy making process, timber legality, private forest, stakeholder.

*Correspondence author, email: mulyaningrum_05@yahoo.co.uk, telp.+62-811-2285-503

\section{Introduction}

Since the 1960s and 1970s, public policy analysts conducted series of conventional policy analysis. These starting from the stages of defining the problem, followed by predicting, prescripting, describing, and evaluating the policy. The goal was to help policy makers in providing alternative solutions in policy-making processes. Policy analysts considered that the policy decision is the manifestation of rational thought. At this point, analysts did not include other factors in the policy-making process, such as power, personal relationships, strategic behavior and strategic use of information (Lindblom 1959). Making a policy is a social process among the actors, and not a rational attempt to find the optimal solution of problem formulation (Sutton 1999). Sutton (1999) and IDS (2006) suggested that the policy-making process is not a rational effort. The implication is that the process should be examined from political factors, interests, actors, networks, discourses, and policy narratives. Policy-making process should integrate various differences, so the actors could explore interests in formulating policy narrative in limited time (Keely \& Scoones 2000).
During this time, policy analysts believed that the decisions of policy makers are the manifestation of rational thought, that consider the policy decisions was separated from the implementation. Sometimes appeared argumentation that the policy was good substance but bad in implementation. It was a result from the process of missdefining the problem: only consider problem which was actually just a symptom, so that the formulation recipes of policy did not result in any good changes (Kartodihardjo 2008).

Process of policy analysis is a series of intellectual activity which is essentially political matter. Political activity is described as the process of making a policy and visualized in a series of interrelated stages. This is initiated by agenda setting and followed by policy formulation, adoption, implementation, and evaluation respectively (Dunn 2003). As a process, making a policy could not avoid political activities. Policy analysis could be influenced by policy makers and affected parties to attain particular goals. Policy makers and affected parties that affected by policies are reffered as stakeholder. Stakeholder also defined as who has been influenced by certain decision and action they 
should take as their responses, also as who has the power to influence the policy result (Mitchell et al. 1997; Freeman 2010).

Some stakeholder theories define stakeholders as groups or individuals "that without the support of the organization would cease its existing" (Bowie 1988). Meanwhile, another wider and more normative definition said that stakeholders are "natural entities that are affected by the performance of the organization". This definition includes a life and non-life entity, or even the construction of mental-emotional (Starik 1995; Hubacek \& Mauerhofer 2008). Fletcher et al. (2003) defines stakeholders as people with an interest or concern on the issue. Participation of stakeholders is important in the process of decision-making of public policy. Although this is a vital first step in any participatory exercise, stakeholders are often identified and selected on an ad hoc basis. This has the potential to marginalize important groups, bias results, and jeopardize long-term viability and support for the process.

The Ministry of Forestry Regulation No. P.38/MenhutII/2009 jo. No. P.68/Menhut-II/2011 jo. No. P.45/MenhutII/2012 are public policies on timber legality. The policies regulate diverse stakeholders in utilizing timber forest products. Timber, particularly harvested from private forests, have several problems. In 2013, the Directorate General of Forest Utilization (BUK) of the Ministry of Forestry targeted that all forest management units either at the state or private forest areas to implement the policy on timber legality. However, the policy receives low responds from farmers who manage private forests, and that make the policy fails to attain the target. Such condition shall be investigated by conducting identification its causes through stakeholders mapping on influences and interests.

The above background brings the authors to conduct this study with the main objective to identify and measure the relationships between stakeholders that have influence on the process of policy-making for defining legality of timber on private forests. Through stakeholder analysis, it will be able to: (1) know aspects of social and natural phenomena are affected by the decision, (2) identified individuals, groups and organizations which can affected by or affect the parts of the phenomenon (this might include non-human, non-life, and future generations), and (3) prioritized the individuals and groups to involve in the decision-making process (Reed etal.2009).

\section{Methods}

The research was conducted from November 2011 to December 2012. Collection of data was carried out within the management unit of private forests that implemented the P. 38/2009 policy on timber legality. These include the unit of Community Logging Giri Mukti Wana Tirta (Comlog GMWT) of the District Central Lampung in Lampung Province, Koperasi Serba Usaha Asosasi Pengrajin Industri Kecil (KSU APIK) of the District Buleleng in Bali Province, Koperasi Hutan Jaya Lestari (KHJL) of District Konawe in South East Sulawesi Province, and Koperasi Wana Lestari Menoreh (KWLM) of the District Kulonprogo in DI Yogyakarta.

In October 2011, the management unit KHJL, Comlog
GMWT has been Timber Legality Assurance System (TLAS) certified (mandatory mechanism). For the same mechanism, KSU APIK has been certified in October 2012. KHJL has been certified by Forest Stewardship Council (FSC) (voluntary mechanism). Meanwhile, KWLM just has been certified by FSC for a comparison.

The research used qualitative approaches outlined by Creswell (2012), where the sampling technique used were purposive and snowball. All data were collected from literature studies, field observations, and depth interview by referring to the key questions. The data were then analyzed by using descriptive-qualitative approach. In-depth interviews was conducted to 5 key persons of the key stakeholders category. On the category of key stakeholders, 12 keypersons were depth-interviewed, while there were 22 keypersons in the category of supporting stakeholder. Field observations have been carried out to determine the geographical, socio-economic, and cultural conditions. Literature studies have also been done by reviewing documents tracking of policy-making process of the timber legality between 2003-2013. The documents were that of the timber legality regulation of P. 38/2009, and its amendments follow (P. 68/2011, P. 45/2012), and its derivatives regulation (P.06/2009, P.02/2010, P.68/2011), and P.8/2012. Scientific studies document tracking of timber legality were conducted, both published and unpublished.

Stakeholder analysis is done as a method to analyze the actors involved in the activity (Bryson 2004). Observations on stakeholder participations in the process of policymaking for timber legality on private forests were conducted by using stakeholders approach. The analysis is conducted to understand the extent of diverse interests among the stakeholders (Friedman \& Miles 2004). The analysis that was used is a modification analysis stakeholder developed by ODA (1995), Reitbergen et al. (1998), and Mayer (2005) as follows:

1 Drawing up a stakeholder table, by:

a identify and list the potential stakeholders,

b classify the stakeholders into groups of primary stakeholder, secondary stakeholder, and key stakeholder,

c identify the stakeholders interests (over and hidden) regarding to their problems and its objectives. Each stakeholder may have several interests.

2 Assessing the interests of each stakeholder member based on their active involvement into achieve the successful process of policy-making for timber legality on private forests. The positive interests is given with high value, while the negative interests is given with low value, or unknown.

3 Assessing the influence as a reflection of level of power being held by certain stakeholders in influencing the process of policy-making for timber legality on private forests. The higher score is given to the higher authority policy maker, and low score for lower authority.

4 Identifying assumptions that influence the process of policy-making for legality of timber on private forests

5 Performing analysis rights, responsibilities, revenues, and relationships (4Rs) (Salam \& Naguchi 2006). The 
4Rs analysis comprises 2 components: (1) assessment of the balance of rights, responsibilities, and revenues (3Rs) both within and between stakeholders, and (2) assessment of the status of the relationships between stakeholders.

1 Analysis of the balance of stakeholders' through capacity mapping of stakeholder into 3Rs (rights, responsibilities, revenues). With steps:

a Literature study of the research area is necessary to determine the backgrounds of the area, including social, economy, cultural, historical, geographic difference, political context, legal, and fiscal background.

b Identifying the necessary capacities according to $3 \mathrm{Rs}$ through the role negotiation phase.

2 Analysis of the relationships between stakeholders by using pair wise matrix of interests and coding their relationships. Relationship is analysis according to the following factors:

a the quality of relationships, which indicate a possibility of a stakeholders role in negotiation phase between conflicting parties,

$\mathrm{b}$ the strength of relationships, regarding to the frequency and contact intensity between parties,

c the formality of relationships, certain types of informal relationships may allow stronger parties to impose their opinion on more vulnerable groups and create an external intervention in order to achieve tangible impacts,

d the dependency between stakeholders, a mediator might be necessary to justify the bargaining position of stakeholders. To be effective, incentives might be needed in a regulatory-type dependency; technical dependency might require behavior changes, while social dependency might have more complexity than the others.

\section{Results and Discussion}

Stakeholders mapping It was identified that there were 17 stakeholders involved in the policy-making process of timber legality on private forests. These stakeholders can be further categorized into primary stakeholder (Table 1).

Primary stakeholder has been directly affected by the policy on timber legality either in term of positive or in negative manners. In this study, the primary stakeholders include private forest farmers (PFF) in District South Konawe, Central Lampung, Buleleng, Kulonprogo, and ministry of forestry as the key stakeholders who play important role due to its high legal authority in policymaking. In other words, the key stakeholder has influence and high interests during the process of policy-making on timber legality.

The secondary stakeholder serves as a mediator in the process of delivering supports. This type of stakeholder has indirect relationships with policy on timber legality, but it concerns with any decisions related with timber legality. Such stakeholders include provincial forest service and district forest service, multi-stakeholder forestry programme-II (MFP-II), certification body, Lembaga Ekolabeling Indonesia, and non government organization (NGo) (either as supervisor or as monitoring body on the process of policy-making). It also includes academician (either who pro or cons the process of policy-making), and Europan Union/EU representation in the form support project of FLEGT (Forest Law Enforcement, Governance, and Trade).

The stakeholder mapping shows positions of each stakeholder with its influence and interests in the policy process on defining timber legality on private forests. The ministry of forestry as the key stakeholder is positioned at the higher interests and influence. Regarding the position of forest services at the provincial and district levels, these 2 agencies has low influence to the decision made by the central government, although they can propose their suggestions to the central level. Meanwhile, the position of EU-FLEGT and MFP-II hold high influence and high interests, even though they belong to the secondary stakeholder. They posses high authority in the process of making decision, particularly for policy timber legality on private forests.

Table 1 Identification and categorization of stakeholders

\begin{tabular}{llll}
\hline $\begin{array}{c}\text { Categorization of } \\
\text { stakeholders }\end{array}$ & \multicolumn{1}{c}{ Stakeholders } & Interests & Influences \\
\hline Key stakeholder & Ministry of Forestry & High & High \\
\hline Primary stakeholder & Private Forest Farmers (PFF) Konawe Selatan & Low & Low \\
& Private Forest Farmers (PFF) Lampung Tengah & Low & Low \\
& Private Forest Farmers (PFF) Buleleng & Low \\
& Private Forest Farmers (PFF) Kulonprogo & Low & Low \\
& & & Low \\
\hline Secondary stakeholder & Prov. Forest Service & High & Low \\
& District Forest Service & High & High \\
& Europan Union (EU-FLEGT) & High & High \\
& Multistakeholder Forestry Programme-II & High & Low \\
& (MFP-II) & High & Low \\
& Certification body & High & Low \\
& Non Goverment Organization (NGo) assistant & Low & How
\end{tabular}

Data analysis based on un-structured interview (2010-2013) being interpreted by the researchers. 
The concept of dependency is the main problem in developing countries when adapting to the development concept of developed countries (Herath 2008). With regard to the international relationships, Wallerstein (1974) suggests to make certain categorization into core, semi-periphery, periphery, and external. The relationships between developed countries who provide support (funding) to the developing countries falls into the category of "coreperiphery". In this type of relationship, developed country is considered a core, who receives most benefits from the agreement with developing country, or the periphery. Such condition stimulates leakage at the periphery country toward the core country, that because interests to exploit benefits as much as possible (Britton 1982). Such behavior of maximizing benefits happens with the Europan Union Timber Regulation (EUTR) which is proposed by EU in a form support project of FLEGT. Furthermore, this is then manifested in a form of Voluntary Partnership Agreement (VPA). That voluntary agreement is then enforced into a binding agreement for Indonesia. From the case of EU agreement, it shows high influence of the core party and also their interests. As a consequence, it is necessary for the periphery country to have bargaining position to balance the influence from the core party. Other important factor is in a form of commitment of bureaucracy to enforce the goals of welfare for both the state and country. According to Nugroho (2011), international relationships are not merely require capacity of government to negotiate with other agencies, but it concerns with professionalism and integrity of the staffs.

From the mapping of primary stakeholder, it is shown that the 6 farmer groups of private forests are considered as the subject being affected by the policy, but with low influence. The group also identified in the positions for not having interests in the policy. This means that benefits from timber legality have not been flown into private forest farmers. With respect to low interests of private forest farmers it can be explained from origin of policy on timber legality that come from interests of national and international, and not based on need of people.

The policy on timber legality was formulated based on assumption that the implementation of verified timber legality could decline the rate of illegal logging and attain good forest governance. The assumption means that if all timber users were certified, theoretically, timber volume that came from illegal activities will decline significantly, then forms price-premium (Darmawan et al. 2012). However, the assumption has not been realized where the private forest farmers have not receive higher price from their timber. When government will impose certain intervention for policy target to conduct certification, there is certain

Table 2 Stakeholders capacities based on responsibilities, rights, and revenues (3Rs)

\begin{tabular}{|c|c|c|c|}
\hline Stakeholder & Responsibilities & Rights & Revenues \\
\hline Ministry of Forestry & $\begin{array}{l}\text { To do bit of policy for timber } \\
\text { legalitry (3) }\end{array}$ & $\begin{array}{l}\text { Policy-making for timber } \\
\text { legality (5) }\end{array}$ & $\begin{array}{l}\text { Revenue from timber } \\
\text { taxes (5) }\end{array}$ \\
\hline EU-FLEGT & $\begin{array}{l}\text { To approve all of timber comply of } \\
\text { legality }(0)\end{array}$ & $\begin{array}{l}\text { To applic ate timber legality } \\
\text { regulation } \\
(5)\end{array}$ & Unknown (0) \\
\hline MFP-II & To manage of policy process (4) & $\begin{array}{l}\text { Fasilitation of policy-making } \\
\text { process (5) }\end{array}$ & $\begin{array}{l}\text { Sustainability of the } \\
\text { project (5) }\end{array}$ \\
\hline Pro academicians & $\begin{array}{l}\text { Provide information relevant to } \\
\text { science policy (3) }\end{array}$ & $\begin{array}{l}\text { Fostering the course of the } \\
\text { policy-making process (4) }\end{array}$ & Unknown (0) \\
\hline Certification body & $\begin{array}{l}\text { The audit process according to the } \\
\text { principles (4) }\end{array}$ & $\begin{array}{l}\text { Conduct the audit process } \\
\text { (4) }\end{array}$ & $\begin{array}{l}\text { Direct revenues from } \\
\text { certification }(5)\end{array}$ \\
\hline Ngo assistant & $\begin{array}{l}\text { Conduct the appropriate mentoring } \\
\text { mission (3) }\end{array}$ & $\begin{array}{l}\text { Private forest farmers } \\
\text { assisting in carrying out the } \\
\text { policy (3) }\end{array}$ & $\begin{array}{l}\text { Direct revenues from } \\
\text { certification (3) }\end{array}$ \\
\hline Cons academicians & $\begin{array}{l}\text { Provide information relevant to } \\
\text { science policy (5) }\end{array}$ & $\begin{array}{l}\text { Criticize the content and } \\
\text { implementation of the } \\
\text { policy (4) }\end{array}$ & None $(0)$ \\
\hline LEI & None $(0)$ & $\begin{array}{l}\text { Oversee the process of } \\
\text { policy making (5) }\end{array}$ & None $(0)$ \\
\hline Prov. Forest Service & Duties mandated by policy (2) & Provide policy proposals (2) & None $(0)$ \\
\hline $\begin{array}{l}\text { District Forest } \\
\text { Service }\end{array}$ & Duties mandated by policy (2) & Provide policy proposals (2) & None $(0)$ \\
\hline NGo for monitoring & None $(0)$ & $\begin{array}{l}\text { Monitoring the verification } \\
\text { process (1) }\end{array}$ & None $(0)$ \\
\hline PFF South Konawe & $\begin{array}{l}\text { Land management with wood } \\
\text { commodities ( } 2 \text { ) }\end{array}$ & Sales of timber (5) & $\begin{array}{l}\text { Direct income from sales } \\
\text { of timber }(0)\end{array}$ \\
\hline PFF Central Lampung & $\begin{array}{l}\text { Land management with wood } \\
\text { commodities (4) }\end{array}$ & Sales of timber (5) & $\begin{array}{l}\text { Direct income from sales } \\
\text { of timber }(0)\end{array}$ \\
\hline PFF Buleleng & $\begin{array}{l}\text { Land management with wood } \\
\text { commodities (5) }\end{array}$ & Sales of timber (5) & $\begin{array}{l}\text { Direct income from sales } \\
\text { of timber }(0)\end{array}$ \\
\hline PFF Kulonprogo & $\begin{array}{l}\text { Land management with wood } \\
\text { commodities (5) }\end{array}$ & Sales of timber (5) & $\begin{array}{l}\text { Direct income from sales } \\
\text { of timber (5) }\end{array}$ \\
\hline
\end{tabular}

- Data analysis based on un-structured interview (2010-2013) and literatur study (2003-2013) being interpreted by the researchers

by using relative-weight.

- Score 0-5 is relative weighted from 3Rs that explains: the higher score the higher weighting value for Rs.

- PFF: Private Forest Farmers. 
expectation for certification to bring higher benefits (Rametsteiner 2002). Market instruments, such as pricepremium and improved market access are considered as incentives for forest managers in sustainable forest management (Rametsteiner \& Simula 2003; Maryudi 2005; Lastini 2011). The forest policy on timber legality is required to create incentive of price-premium for the forest farmer. Previous study in Malaysia showed that the relationship of certification and price-premium (Kollert \& Lagan 2007), and there are increase in market access and reputation of the private company after certification (Bouslah et al. 2010).

Stakeholders capacity Analysis of capacity of the stakeholders can be done using the 4Rs method. From the capacity mapping it shows the stakeholders with high responsibilities are MFP-II, certification body, cons academicians, and private forest farmers in Buleleng and Kulonprogo. Stakeholders with the highest responsibilities are ministry of forestry, EU-FLEGT, MFP-II, pro academicians, and all the private forest farmers member. The highest benefits flow into ministry of forestry and certification body. Capacity of stakeholder can be observed from the balance of $3 \mathrm{R}$ as presented in the Table 2 .
The imbalanced on 3Rs occurred at key stakeholder of ministry of forestry. The ministry of forestry applies instrumentalist model to create its rights in developing the policy on timber legality. That model aims to improve any weakness of implementation occurred in the past (Sutton 1999). Implementation will be limited by insufficient infrastructure for policy-making. Including the availability of funding for verification. The fail in achieving target of implementation set in March 2013 (the start time of EUTR) is mainly due to unattained price-premium as promised to the private forest farmers. None of forest farmers conduct verification with their own funding. The farmers will not take risks to spend higher costs with lower return (Tim Foretika 2011). The imbalanced of 3 Rs on PHR is caused by high responsibilities and rights that have not been accompanied by higher incentives.

Failed in achieving assumption of price-premium will result into imbalance 3 Rs primary stakeholder as subject of the policy. Revenues being expected by private forest farmers were not attained due to failure in formation of market price. International market preferred forest product that have been certified by Forest Stewardship Council (FSC) (Purnomo et al. 2011). KWLM Kulonprogo has been

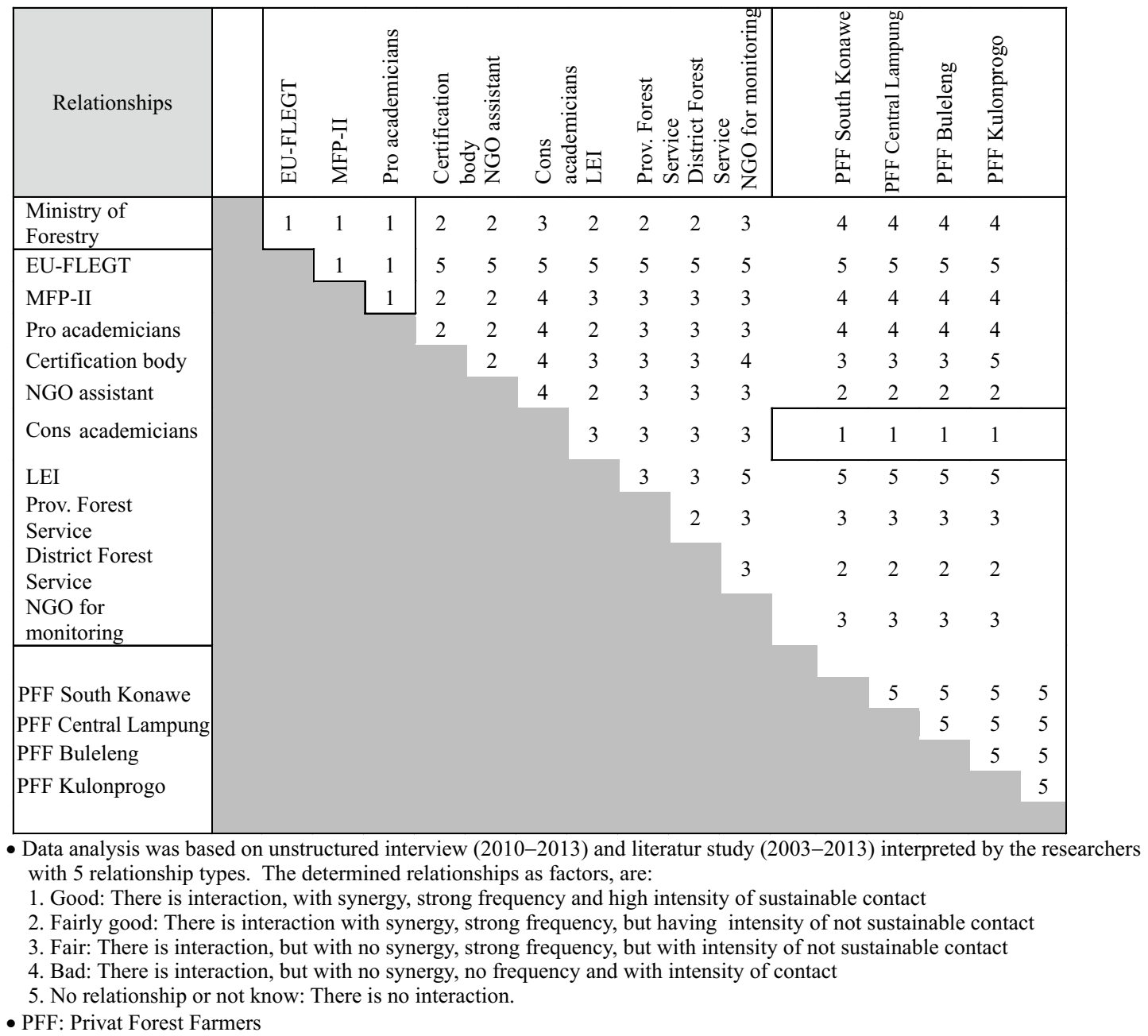

Figure 1 Matrix of relationships among stakeholders. 
certified by FSC, therefore there is a balance in 3Rs. In conclusion, the market driven condition is necessary to determine the certification scheme that may provide premium price for the primary stakeholders.

Relationships of stakeholder The balanced of 3Rs relationships provide consideration for quality of relationship among stakeholders involved. The relationships are presented in term of pair wise as it is shown in Figure 1.

One of the most fundamental challenges for policy analysts to support policy making is to improve their relationship with policy making processes (Hermans \& Thissen 2009). Key stakeholders have a strong relationship with the secondary stakeholders. In the other side, key stakeholders have a weak relationship with the primary stakeholders. These situations are in contrary with ideal situation, in which the strong relationship should be existed between key and primary stakeholders. This present situation has resulted in imbalance of the 3Rs at key stakeholders. The imbalanced $3 \mathrm{Rs}$ at key stakeholder come from inability of accomplishing the enabling condition, causing the certification does not work optimally. Key stakeholders tend to strengthen the relationship with the core state to resolve the issues of enabling condition.

\section{Conclusion}

Interests and influences do not consider private forest farmers as the primary stakeholder in the process of policy formulation. Both national and international agencies have strong interests on the process. Being supported by strong authority and interests, the process remain in status quo that constraint NGOs and cons academicians to shift the process. The imbalance of 3Rs (responsibilities, right, revenues) for farmers as the manager of private forest were due to the high responsibilities but with low incentives that create burden and result into in-effective policy implementation. Strong relationships between the ministry of forestry as a key stakeholder with the state as a core have not empowered their relationships with farmers on private forests as the primary subject. As result, policy assumptions cannot be implemented properly.

\section{Recommendation}

Policy assumptions of timber legality in private forests need to be re-examined, so that the gap between the texts of the legislation can be implemented based on the realities on the ground.

\section{References}

Bouslah K et al. 2010. The impact of forest certification on firm financial performance in Canada and the US. Journal of Business Ethics 96: 551-572. http://dx.doi. org/10.1007/s10551-010-0482-5.

Bowie SN. 1988. The moral obligations of multinational corporations. In: LuperFoy S, editor. Problems of International Justice. Boulder: Westview Press.

Bryson JM. 2004. What to do when stakeholder matter. Stakeholder identification and analysis techniques.
Public Management Review 6 (1): 21-53. http://dx.doi. org/10.1080/14719030410001675722.

Britton SG. 1982. The political economy of tourism in the world. Annals of Tourism Research 9(3): 331-358. http://dx.doi.org/10.1016/0160-7383(82)90018-4.

Creswell JW. 2009. Research Design Qualitative \& Quantitative Approaches. Third Edition. California: Sage Publications.

Darmawan AH, Nugroho B, Kartodihardjo H, Kolopaking LM, Boer R. 2012. SVLK, Jalan Menuju REDD +. Jakarta: Forest Governance and Multistakeholder Forestry Programme.

Dunn WN. 1994. Public policy analysis: an introduction. Second Edition. New Jersey: Prentice-Hall Inc.

Fletcher A et al. 2003. Mapping stakeholder perceptions for a third sector organization. Journal of Intellectual Capital 4(4): 505-527. http://dx.doi.org/10.1108/1469 1930310504536.

Freeman RE. 2010. Strategic management: a stakeholder approach. New York: Cambridge University Press.

Friedman AL, Miles S. 2004. Stakeholder theory and communication practice. Journal of Communication and Management 9:89-97.

Grimble R, Chan MK. 1995. Stakeholder analysis for natural resource management in developing countries: some practical guidelines for making management more participatory and effective. Natural Resources Forum 19: 113-124. http://dx.doi.org/10.1111/j.1477-8947. 1995.tb00599.x.

Herath D. 2008. Development discourse of the globalists and dependency theorists: Do the globalisation theorists rephrase and reword the central concepts of the dependency school? Third World Quarterly 29(4): 819-834. http://dx.doi.org/10.1080/0143659080 2052961 .

Hermans LM, Thissen WAH. 2009. Actor analysis methods and their use for public policy analisyst. European Journal of Operational Research 196: 808-818. http://dx.doi.org/10.1016/j.ejor.2008.03.040.

Hubacek K, Mauerhofer V. 2008. Future generations: economic, legal and institutional aspects. Future 40: 413-423. http://dx.doi.org/10.1016/j.futures. 2007.10.001.

Kartodihardjo H. 2008. Diskursus dan aktor dalam pembuatan dan implementasi kebijakan kehutanan: Masalah kerangka pendekatan rasional. Jurnal Manajemen Hutan Tropika (14)1: 19-27.

Kollert W, Lagan P. 2007. Do certified tropical logs fetch a market premium? A comparative price analysis from 
Sabah, Malaysia. Forest Policy and Economics 9 (7): 862-868. http://dx.doi.org/10.1016/j.forpol.2006.03. 005 .

Lastini T, Suhendang E, Jaya INS, Harjanto, Purnomo H. 2011. Tipologi desa berdasarkan variabel penciri hutan rakyat. Jurnal Penelitian Hutan Tanaman 8(3): $155-168$.

Lacher RG, Nepal SK. 2010. Dependency and development in northern thailand. Annal of Tourism Research 37(4): 947-968. http://dx.doi.org/10.1016/j.annals.2010. 03.005 .

Lindblom CE. 1959. The science of muddling through. Public Administration Review 19: 79-88. http://dx.doi. org/10.2307/973677.

Maryudi A. 2005. Beberapa kendala bagi sertifikasi hutan rakyat. Jurnal Hutan Rakyat 7(3): 25-39.

Mayer J. 2005. Power Tools: The Four Rs. Institute for Environment and Development. http://www.policypowertools.org. [25 Desember 2012].

Mitchell RK, Agle BR, Wood DJ. 1997. Toward a theory of stakeholder identification and salience: defining the principle of who and what really counts. Academy of Management Review 22(4): 853-888.

Nugroho R. 2011. Public Policy. Jakarta: Elex Media Komputindo.

ODA. 1995. Guidance note on how to do stakeholder analysis of aid projects and programmes. Social Development Departement. Overseas Development Administration. http://www.euforic.org/gb/stake1.htm \#intro. [23 Desember 2012].

Purnomo H, Irawati RH, Wulandari R. 2011. Kesiapan produsen mebel di Jepara dalam menghadapi sertifikasi ekolabel. Jurnal Manajemen Hutan Tropika 17(3): 127-134.

Rametsteiner E. 2002. The role of governments in forest certification a normative analysis based on new institutional economics theories. Forest Policy and Economic 4: 163-173. http://dx.doi.org/10.1016/ S1389-9341(02)00004-7.

Rametsteiner E, Simula M. 2003. Forest certification-an instrument to promote sustainable forest management? Journal of Environmental management 67: 87-98. http://dx.doi.org/10.1016/S0301-4797(02)00191-3.

Reed MS et al. 2009. Who's in and why? A typology of stakeholder analysis methods for natural resource management. Journal of Environmental Management 90: 1933-1949. http://dx.doi.org/10.1016/j.jenvman .2009 .01 .001 .

Reitbergen J, McCracken, Narayan D. 1998. Participation and social assessment, tools and techniques. The World Bank. http://importal.net/library/content/tools/ biodiversity-conservation-tools.

Salam MA, Noguchi T. 2006. Evaluating capacity development for participatory forest management in Bangladesh's Sal forests based on '4Rs' stakeholder analysis. Forest Policy and Economics 8: 785-796. http://dx.doi.org/10.1016/j.forpol.2004.12.004.

Starik M. 1995. Should trees have managerial standing? Toward stakeholder status for non-human nature. Journal of Business Ethics 14: 207-217. http://dx.doi. org/10.1007/BF00881435.

Sutton R. 1999. Policy Process: An Overview. Working Paper 118. Overseas Development Institute. London SW1E 5 DP: Portland House. Stag Place.

Tim Foretika. 2011. Analisis Biaya Manfaat Penerapan Sistem Verifikasi Legalitas Kayu. Bogor: MFP-II dan FOReTIKA

Wallerstein I. 1974. The Modern World System: Capitalist Agriculture and The Origins of the European World Economy in the Sixteenth Century. New York: Academic Press. 